\title{
„Nienawidzę tej szkoły!” 0 odrzuceniu, niezrozumieniu i o tym, jak wiele zależy od człowieka
}

\begin{abstract}
Abstrakt
Historia Krzysia, odtworzona przez Autorkę na podstawie rozmów z jej koleżanką, pokazuje sytuację „klasowego głupka”. Chłopca z podejrzeniem ADHD, u którego przez kilka lat lekarze nie potrafili postawić jednoznacznej diagnozy. Jak wielu „Innych”, Krzyś doświadczył odrzucenia przez część nauczycieli, rówieśników i ich rodziców oraz niektórych członków rodziny. Wcześnie poznał smak samotności, niezrozumienia, agresji, lęku przed szkołą, upokorzenia, bezradności. Opowieść o Krzysiu i jego szkolnych problemach pokazuje, jak różne mogą być postawy osób związanych ze szkołą wobec dziecka postrzeganego jako „Inny”. Jak wiele zależy od człowieka i jego wrażliwości, umiejętności dostrzegania problemów i chęci spieszenia z pomocą. Opowieść ta jest też punktem wyjścia do refleksji nad modelem relacji uczeń - nauczyciel w szkole masowej i alternatywami dla niego, a także nad funkcjonowaniem szkół w społeczeństwie hołdującym kulturze upokarzania, wrogości i odrzucenia.
\end{abstract}

Słowa kluczowe: odrzucenie, szkoła, upokorzenie, inność/odmienność, nadwrażliwość.

\section{„I Hate That School!” On Rejection, Lack of Understanding and How Much Depends on One Person}

\begin{abstract}
The story of Krzyś (Chris), which the author reconstructed based on talks with a friend, shows the situation of the "class clown", the boy suspected of having ADHD whom the doctors were unable to diagnose explicitly for some years. Like many such "Others", Chris experienced rejection by some of his teachers, peers and their parents and by some members of his own family. Early in life he knew the bitterness of loneli-
\end{abstract}

\footnotetext{
* Instytut Archeologii i Etnologii PAN, Warszawa.
} 
ness, lack of understanding, aggression, fear of school, humiliation and helplessness. The story of Chris and his school problems shows how the attitudes of various persons in a school who deal with a child perceived as "different" can vary. How much depends on the particular person, on his or her receptiveness, ability to notice the problems and eagerness to help. The story is also a starting point for reflection on the model of the pupil - teacher relationship in a large school system as well as its alternatives; and more generally - on the functioning of schools in a society dominated by a culture of humiliation, hostility and rejection.

Keywords: rejection, school, humiliation, dissimilarity, supersensitivity.

Szkoła, w której dziecko nie czuje się bezpiecznie, która wzbudza lęk, powinna być prawnie zabroniona. Człowiek, który ma zagrożone poczucie własnej wartości, gdy czegoś się boi, nie jest w stanie się rozwijać, bo skupia się na obronie przed lękiem

(Szkoła szczęśliwszych... 2016: 31) ${ }^{1}$

\section{Odrzuceni „odmieńcy”}

Odrzucenie boli. Zawsze. Niezależnie od tego, jakie są jego przyczyny, ile mamy lat, kim jesteśmy. Wiele osób poznało jego smak już $w$ dzieciństwie - w domu, w przedszkolu, w szkole, na placu zabaw.

Przyczyną odrzucenia bywa „inność”, odmienność, klasyfikowana w opozycji do tego, co postrzegamy jako „swoje”, własne, bliskie. „Innymi” mogą być członkowie grupy różniącej się od tej, z którą identyfikujemy się pod względem kulturowym, religijnym, językowym, etnicznym, można ich jednak również spotkać w tej samej grupie (etnicznej, kulturowej, religijnej, językowej). „Odmieńcy” stanowią specyficzną kategorię „«swoich-obcych»” (Perzanowski 2009: 49)². Nie ma tu „dystans[u] etniczn[ego], religijn[ego], rasow[ego]” (tamże). Wyróżniają ich np. specyficzne sposoby zachowania, postrzegania rzeczywistości i reagowania na nią, upodobania, postępowania według wzorów odrębnych od tych, które kreuje,

\footnotetext{
1 Słowa te zostały wypowiedziane przez Roberta Kwaśnicę, autora książek: Dwie racjonalności. Od filozofii sensu ku pedagogice ogólnej oraz Dyskurs edukacyjny po inwazji rozumu instrumentalnego. O potrzebie refleksyjności, współautora raportu Reforma kulturowa 2020, 2030, 2040 (za: Szkoła szczęśliwszych... 2016: 30).

2 Badania Andrzeja Perzanowskiego dotyczyły „odmieńców” zwanych „wioskowymi głupkami”. Inspiracją dla niego były prace Michela Foucaulta, który stwierdził, że „we wszystkich wioskach zamieszkiwała osoba zwana "głupkiem wsiowym»" (Foucault 2000: 93) (Perzanowski 2009: 57). Idąc tropem wskazanym przez wspomnianych badaczy, wychodząc poza społeczności wiejskie, można, moim zdaniem, podjąć badania w innych środowiskach, gdzie z pewnością spotkamy różne postacie „głupków”. Funkcjonują oni np. w rodzinach, w szkołach, w miejscu pracy, w różnorodnych społecznościach lokalnych.
} 
akceptuje i stara się narzucać większość lub ci, którzy po prostu czują się silniejsi i pewni, że ich sposób bycia jest lepszy, którzy nie tolerują odmienności.

„To, co odmienne (...) [bywa] odczytane jako upośledzające, gorsze, oburzające, zawstydzające, budzące śmiech, zgorszenie, [ale też] fascynujące” (tamże: 47). Inny/odmieniec często funkcjonuje jako „wioskowy głupek” (tamże: 57). Staje się bohaterem „opowieści, plotek, wartościowania (...)” (tamże: 47).

O odrzuceniu może decydować sposób bycia, wygląd, brak sprawności fizycznej, choroba, przynależność do określonego środowiska, ubóstwo. Bycie innym/odmieńcem/„wioskowym głupkiem” nierzadko skazuje człowieka na samotność, zepchnięcie na margines społeczności, upokorzenie. Z niechęcią środowiska, brakiem zrozumienia i akceptacji stykają się np. osoby nadwrażliwe ${ }^{3}$. Takim osobom trudno jest funkcjonować w świecie pełnym hałasu, agresji, przemocy, rywalizacji, wrogości, nieustannych zmian, coraz szybszego tempa życia (Zeff 2008: 9, 18, 19, 32, 33, 49). „Przeciętnie wrażliwi”, stanowiący zdecydowaną większość w każdym społeczeństwie, na ogół nie rozumieją, dlaczego nadwrażliwi denerwują się w sytuacjach, w których oni sami nie rejestrują żadnych bodźców, mogących wywołać niepokój, nadmierne pobudzenie, rozdrażnienie (Zeff 2008: 31-36), nadwrażliwi z kolei oczekują zrozumienia, akceptacji. Ich oczekiwania rzadko zostają spełnione, często natomiast - podobnie jak inni „odmieńcy” - odbierają sygnał: „coś z tobą jest nie tak” (tamże: 31). Są postrzegani jako ludzie niezaradni, pozbawieni „realizmu życiowego”, nieprzystosowani. „Świat” ich nie rozumie, skazuje na samotność, odrzuca. Nie zauważa „wielki[ch] uzdolni[eń]” i „niezwykłoś[ci] [ich] dróg”, zmuszając do leczenia, podczas gdy to oni powinni „leczyć innych" (Dąbrowski b.d.: 1).

Koncepcja dezintegracji pozytywnej, sformułowana przez Kazimierza Dąbrowskiego, pozwala spojrzeć na osoby nadwrażliwe nie przez pryzmat choroby, lecz rozwoju psychicznego. Na podstawie badań przeprowadzonych wśród uczniów uzdolnionych artystycznie, intelektualnie i sportowo, wykazujących wysoki poziom emocjonalności i wrażliwości Dąbrowski dowiódł, że wiele zachowań, kwalifikowanych przez psychologów i psychiatrów jako patologie, nie ma nic wspólnego z zaburzeniami psychicznymi (więcej patrz: Dąbrowski 1958, 1975a, 1975b, 1979) 4 . Zostało to potwierdzone przez innych badaczy. Okazało się, że „nadwrażliwość (supersensitivity) (...) jest [często] źródłem (...) wybitnych zdolności intelektualnych, umożliwia bowiem asymilację niezwykłej ilości sensorycznych doznań" (Cruishank 1963, za: Freeman 1985) (za: Limont 2014: 14). Najczęściej jednak

\footnotetext{
${ }^{3}$ Ich centralny system nerwowy silniej niż w przypadku „przeciętnie wrażliwych” przetwarza bodźce płynące z otoczenia, powodując długotrwały niepokój, zmęczenie, wyczerpanie, uczucie „obezwładnienia”, frustrację, zamykanie się w sobie, rozdrażnienie, nastroje depresyjne (Zeff 2008: 18, 22-23, 32, 34, 166); na temat nadwrażliwych patrz też Aron 1996.

${ }^{4}$ Warto zauważyć, że „[p]ojęcia dezintegracji nie znajdziemy w żadnej z przyjętych klasyfikacji chorób i zaburzeń psychicznych (ICD-10, DSM IVR)” (Gleba 2010: 389).
} 
środowisko, w którym przebywają osoby nadwrażliwe nie dostrzega ich zdolności, koncentrując się na zachowaniach interpretowanych jako naganne, niewłaściwe, na „inności”.

\section{Ted Zeff i Jay}

Dla nadwrażliwych dzieci ogromnym wyzwaniem jest szkoła. Ich delikatny system nerwowy przez wiele godzin dziennie zmuszony jest do funkcjonowania $w$ hałasie, tłoku, pośpiechu, narażony na stres związany z przemocą fizyczną i psychiczną, koniecznością rywalizacji, zmianami pomieszczeń klasowych, nauczycieli i programów. Jeśli po lekcjach nadwrażliwe dziecko wraca do domu, w którym nie znajduje spokoju, wsparcia, akceptacji i zrozumienia, jego system nerwowy poddawany jest działaniu dodatkowych bodźców, wzmagających niepokój i związane z nim napięcia.

Ted Zeff, autor książki Być nadwrażliwym i przetrwać, był uczniem piątej klasy, kiedy wyraźnie uświadomił sobie, że towarzyszy mu stałe uczucie niepokoju. Cierpiał też na bezsenność. Coraz bardziej „[p]rzerażała (...) [go] (...) wielka i hałaśliwa szkoła”, do której chodził (Zeff 2008: 10). Pogłębiały się trudności z koncentracją. Podejmowane przez niego „prób[y] dopasowania się do agresywnego, pełnego bodźców zewnętrznych świata (...)" powodowały jedynie wzrost napięcia (tamże: 11). Psycholodzy, u których rodzice Zeffa szukali pomocy dla dziecka, nie potrafili go zrozumieć. Dopiero po dwudziestu latach, pracując nad doktoratem na temat stresu, Zeff odkrył, że źródłem odczuwanego przez niego permanentnie niepokoju była „wrażliwość i niemożliwość eliminowania bodźców zewnętrznych" (tamże). Zaczął stosować techniki relaksacyjne, zmienił sposób odżywiania. Pracując jako psycholog, dzięki własnym doświadczeniom, doskonale rozumiał problemy innych osób nadwrażliwych i potrafił im pomóc.

Książkę Zeffa czytałam kilkakrotnie ${ }^{5}$. Jeden z jej bohaterów - Jay, odrzucony przez kolegów, nauczycieli i najbliższą rodzinę z powodu zachowań wynikających z jego nadwrażliwości, stał mi się szczególnie bliski. Chłopcy nie akceptowali go, ponieważ nie chciał grać z nimi w piłkę. Wolał „łagodniejsze zabawy - gry w kości lub w klasy z dziewczynkami” (tamże: 224). Z tego powodu dzieci wyśmiały go, przestał więc bawić się z nimi. Środowisko, w którym przebywał, irytowała nieśmiałość i delikatność chłopca. W szkole i w domu niejednokrotnie dawano mu do zrozumienia, że „jest kimś gorszym” (tamże: 225), że „jego introwertyczne zachowania i subtelność są nie do zaakceptowania. Tym bardziej, że jest chłopcem" (tamże: 224). Podczas przerw Jay spacerował samotnie po szkolnym dziedzińcu.

\footnotetext{
${ }^{5}$ Stała się ona dla mnie inspiracją do napisania dwóch artykułów. Jeden z nich, zatytułowany Nadwrażliwi - marginalizowana mniejszość kulturowa, ukazał się w 2012 r., drugi nosi tytuł Nadwrażliwi kulturowi odmieńcy i czeka na opublikowanie w „Etnografii Polskiej”.
} 
Zwróciło to uwagę jednej z nauczycielek ${ }^{6}$. Zaczęła z nim rozmawiać, chcąc zrozumieć przyczyny jego samotności. Dzięki tym rozmowom Jay poczuł się kimś wartościowym, „wyjątkowym” (tamże), długo jednak nie mógł uwierzyć, że jego wrażliwość jest czymś „wspaniałym” (tamże: 225), że to ci, którzy „wyśmiewają się z jego łagodnej natury", postępują niewłaściwie (tamże: 224). Nauczycielka chwaliła chłopca w obecności innych uczniów, podkreślając, że jego wrażliwość jest zaletą (tamże).

Z informacji podanych przez Zeffa nie wynika, czy podjęte przez nią działania wpłynęły na radykalną zmianę zachowań innych uczniów, ich stosunek do nadwrażliwego kolegi. Czy poradził sobie z nieakceptującą go grupą? Jak ułożyły się jego relacje z rodziną? Informacja, że Jay (już jako mężczyzna w średnim wieku) pojawił się w gabinecie Zeffa, wskazuje na to, że nadwrażliwość wciąż była dla niego problemem, obciążeniem. Być może stanowiła powód, dla którego szukał pomocy psychologa. Być może wciąż zmagał się z powracającą (nieprzepracowaną) traumą z dzieciństwa i nadwrażliwością, brakiem wsparcia i zrozumienia ze strony otoczenia, w którym przebywał, z samotnością. Opowiadając swoją historię, dorosły Jay nie krył łez wzruszenia na wspomnienie nauczycielki, która doceniła jego wrażliwość (tamże). Być może nie spotkał nikogo podobnego do niej, dzięki komu mógłby poczuć się człowiekiem wyjątkowym. Jego wyjątkowość, mająca związek z nadwrażliwością, nie została dostrzeżona i doceniona.

\section{Historia Krzysia ${ }^{7}$}

Często myślę o chłopcu, o którym wielokrotnie opowiadała mi koleżanka - synu jej siostrzenicy. Opowieści te były pełne emocji. Słuchałam ich z uwagą, z przejęciem. Nie poznałam osobiście ich bohatera, stał się jednak dla mnie kimś ważnym. Wyobrażałam sobie, jak trudne były jego doświadczenia i jak bardzo musiał być samotny. Interesował mnie jego los. Współczułam jemu i jego rodzicom. Często o niego pytałam. Koleżanka przekazywała mi to, co usłyszała od jego mamy i babci, rozmawiając $\mathrm{z}$ nimi przez telefon lub podczas spotkań $\mathrm{w}$ rodzinnym gronie ${ }^{8}$. W tym miejscu spróbuję uporządkować jej relacje, odtworzyć z pamięci pojawiające się w nich wątki.

Chłopiec od urodzenia sprawiał kłopoty. Często płakał, nie chciał spać, grymasił podczas jedzenia, łatwo się przeziębiał. Nieprawidłowe napięcia w kończynach spowodowały konieczność intensywnej rehabilitacji. Był nadpobudliwy, nerwowy, nieposłuszny, szybko wpadał w złość, domagał się stałej uwagi. Nie potrafił bawić się sam. Nocami budził się z płaczem, krzyczał, wyrywał się, gdy rodzice próbowali go przytulić i uspokoić. Koszmary, powtarzające się każdej nocy, trwały kilka lat.

\footnotetext{
${ }^{6}$ Jay był wówczas uczniem szóstej klasy.

7 Ze zrozumiałych względów imię chłopca zostało zmienione. Nie podano również innych informacji, które mogłyby naruszyć prywatność osób, o których jest mowa w tekście.

${ }^{8}$ Spotkania te były sporadyczne, od domu chłopca i jego bliskich dzieliło ją kilkaset kilometrów.
} 
Na placu zabaw wdawał się w bójki z innymi dziećmi. Zaczepiał je, przeszkadzał w zabawie, próbował narzucać własne pomysły. Nie interesowało go budowanie zamków z piasku, kopanie tuneli w piaskownicy. Nudziły go wiaderka, grabki i foremki, którymi inne dzieci były zachwycone. Uwielbiał przesypywać piasek w dłoniach i obsypywać nim osoby znajdujące się w pobliżu piaskownicy. Stawało się to przyczyną kłótni i przykrych uwag.

Chętnie huśtał się na huśtawce, kręcił na karuzeli, zjeżdżał na zjeżdżalni. Cały czas mówił. Zadawał pytania, komentował zachowania innych, opowiadał historie wymyślone lub znane mu z filmów obejrzanych w telewizji albo w kinie.

Kiedy skończył trzy lata, rodzice posłali go do przedszkola. Bywał tam rzadko. Dużo chorował (infekcje dróg oddechowych, zapalenie uszu, gardła). Kiedy był chory, siedział w domu z dziadkami (rodzicami ojca), którzy go wiecznie strofowali, krytykowali, traktując opiekę nad wnukiem jak „dopust Boży”. Słyszał od nich, że jest niegrzeczny, nieposłuszny, źle wychowany przez matkę ${ }^{9}$. Odmawiał wykonania poleceń, uczestnictwa w proponowanych przez nich zabawach. Nie interesowały go kolorowanki, wycinanki, rozwiązywanie zagadek, rysowanie. Kiedy rodzice lub dziadkowie czytali mu książeczki, przerywał, zadawał mnóstwo pytań, „dopisywał” własną wersję wydarzeń. Miał niesamowitą wyobraźnię. Kreował fabuły, dla których inspiracją często były filmy obejrzane w telewizji. Fascynowało go zło. Było silne, ekspansywne, głośne, a przez to atrakcyjne. Nie przerażała go agresja, brutalność, bezwzględna walka, chamstwo. Kiedy mama powiedziała, że chciałaby, żeby na świecie istniało jedynie dobro, stwierdził: Byłoby nudno. Miał wówczas sześć lat.

Szybkim, zdecydowanym ruchem niszczył wieże z klocków budowane dla niego przez dorosłych. Rozmontowywał zabawki, ciekaw, jak są skonstruowane. Ich składanie nie było już jednak tak interesujące. Nie chciał sprzątać, układać zabawek i książek na półkach lub w specjalnych pojemnikach. Nie potrafił usiedzieć na miejscu. I bez przerwy mówił, powtarzając te same tematy. Należały do nich m.in. historie filmowych bohaterów, których zachowania odtwarzał w szczegółach, doskonale naśladując gesty, głosy, sposób mówienia poszczególnych postaci, odtwarzając z pamięci długie dialogi. W przedszkolu jednak nie chciał występować publicznie. Wstydził się, denerwował, kręcił, zapominał tekstu, robił „głupie” miny.

Przedszkolanki nie sygnalizowały żadnych problemów, w szkole natomiast okazało się, że Krzyś ma kłopoty z koncentracją, z rozumieniem i wykonywaniem poleceń, nie potrafi spokojnie siedzieć i słuchać nauczycielki. Codziennie przynosił uwagi: jest niegrzeczny, nieposłuszny, nadpobudliwy, szybko się nudzi, chodzi po klasie, bez przerwy mówi, przeszkadza, zaczepia dzieci, nie współpracuje z nauczycielką i grupą, wydaje głośne dźwięki (piszczy, krzyczy), wdaje się w bójki. Nauczycielki (w „zerówce” i klasach I-III) twierdziły, że gdyby chłopiec chciał, mógłby zachowywać się inaczej, jak grzeczne dzieci, stawiane mu za wzór. Gdyby chciał...,

${ }^{9} \mathrm{O}$ wpływie ojca na zachowania dziecka nie było mowy. 
ale nie chce! Nikomu nie przyszło do głowy, że przyczyną zachowań odbieranych przez otoczenie jako denerwujące i naganne może nie być świadome działanie, zła wola czy błędy wychowawcze, lecz funkcjonowanie mózgu, nad którym dziecko nie ma kontroli.

W I klasie pani prowadząca dodatkowe zajęcia z rytmiki, po kilku lekcjach, powiedziała mamie Krzysia, że jego udział w spotkaniach nie ma sensu. Nie wykonuje poleceń, nie powtarza układów, kreuje własne scenariusze, nie podporządkowuje się i utrudnia jej pracę. Dodała też: Jeśli nie zaczniecie Państwo działać, stracicie to dziecko!

„Działanie według własnych reguł” i utrudnianie pracy nauczycielom, nieradzenie sobie $\mathrm{z}$ emocjami, nauką i funkcjonowaniem $\mathrm{w}$ grupie, przeszkadzanie innym dzieciom, powtarzające się skargi na chłopca ${ }^{10}$ - wszystko to było powodem coraz częstszych wezwań rodziców na rozmowy z pedagogiem szkolnym i panią dyrektor. Bardzo długo rodzice Krzysia nie odczuwali chęci pomocy ze strony kadry pedagogicznej, prób zrozumienia źródeł kłopotów, przyczyn jego zachowań. Słyszeli, że należy przenieść chłopca do innej szkoły. Nikt nie pytał, czy w nowej placówce jego kłopoty przestaną istnieć, jaka będzie cena zmiany środowiska i konieczności adaptacji do nowych warunków. Najważniejsze, by zniknął on sam.

Rodzice nie poddali się. Zdecydowali, że syn zostanie w szkole. Starali się o umieszczenie go w klasie integracyjnej ${ }^{11}$, okazało się jednak, że niezbędne jest skierowanie z poradni specjalistycznej z wyraźnie sformułowaną diagnozą, by wpisać dziecko na listę uczniów takiej klasy. Trzeba też było czekać aż zwolni się w niej miejsce. Rozpoczęła się wędrówka po przychodniach (państwowych i prywatnych). Tysiące rozmów, orzeczeń, skierowań na kolejne badania, wciąż jednak nie było ostatecznej diagnozy. Czy rzeczywiście „przypadek” chłopca był wyjątkowy i z uwagi na to - trudny do jednoznacznego zdiagnozowania, wymykający się znanym klasyfikacjom? Szansa na umieszczenie dziecka w doskonale funkcjonującej klasie integracyjnej ${ }^{12}$ oddalała się coraz bardziej.

Wędrówki po gabinetach pedagogów, psychologów, psychiatrów, neurologów, nie były jednak bezowocne. Okazało się, że chłopiec ma liczne, wrodzone, „deficyty”. Konieczna była pomoc logopedy, osoby prowadzącej zajęcia z integracji sensorycznej, podjęcie działań mających poprawić tzw. przetwarzanie słuchowe. Chłopiec ćwiczył systematycznie, choć było to dla niego bardzo męczące. Duże znaczenie miał dobry kontakt z osobami prowadzącymi poszczególne zajęcia. Przyjazne relacje z nimi, słowa zachęty, pochwały, poczucie bezpieczeństwa motywowały go do działania. Nie skończyły się jednak problemy z nauką i zachowaniem. Nadal

\footnotetext{
10 Skarżyli się nauczyciele, panie pracujące w świetlicy, dzieci i ich rodzice (ci ostatni znali chłopca jedynie z opowieści własnych pociech).

${ }^{11}$ W szkole, do której chodził Krzyś, były tego typu klasy, obejmujące wszystkie roczniki (od I do VI).

120 tym, że równoległa klasa integracyjna znakomicie funkcjonuje, zapewniając dzieciom fachową opiekę, spokój i bezpieczeństwo, rodzice chłopca wiedzieli od znajomych, których dziecko było jej uczniem.
} 
przeszkadzał nauczycielom, nie panował nad emocjami, łatwo wpadał w złość, był agresywny, chodził po klasie, nie nadążał z notowaniem w zeszycie i wykonywaniem poleceń, pracował znacznie wolniej niż inne dzieci, szybko się zniechęcał, nudził, dekoncentrował.

Stał się klasową ofiarą. Dzieci mówiły o nim: „głupek”, „wariat”, „idiota”, „kretyn”, „wkurzający”. Skarżyły wychowawczyni i rodzicom. Matka jednej z uczennic powiedziała kiedyś mamie Krzysia: Posłałam córkę do szkoły po to, żeby się uczyła, a nie po to, żeby się denerwowała, bo ktoś jej przeszkadza i nie umie się zachowywać. Nie chciała zrozumieć, że chłopiec ma problemy. Uważała, że powinien zostać przeniesiony do innej klasy lub szkoły. Zniknąć razem ze swymi problemami.

Cokolwiek wydarzyło się w klasie, dzieci zrzucały winę na chłopca. Nie potrafił się bronić, zresztą - jak twierdził - wychowawczyni i tak go nie słucha. Koledzy prowokowali bójki, a potem biegli ze skargą, mówiąc, że zaczął je Krzyś. Nikt nie przejmował się obrażeniami, które odnosił. Gdy próbował się bronić, tłumaczyć, przedstawić własną wersję wydarzeń, nauczycielka machała ręką i odwracała się plecami. Nie była ciekawa jego prawdy. Przestał więc cokolwiek wyjaśniać.

Zarówno w „zerówce”, jak i w klasach I-III wychowawczynie nie zastanawiały się nad tym, że chłopiec może uczestniczyć w bójkach, ponieważ został do tego sprowokowany. Może w ten sposób się broni? Nie dostrzegały też jego walorów inteligencji, bogatego zasobu słów, ciekawości świata, wielości zainteresowań, dociekliwości, nie doceniały wysiłku, jaki wkładał w codzienną walkę z własnymi ograniczeniami, „deficytami”, niechęcią środowiska, w którym przebywał, samotnością, zagubieniem, narastającym lękiem. Chodził do szkoły systematycznie, mimo negatywnych uczuć, jakie w nim budziła, panującego w niej hałasu, agresji, poczucia zagrożenia, braku bezpieczeństwa, odrzucenia, niezrozumienia, doświadczenia niesprawiedliwości. Spędzał w niej dziesięć godzin dziennie (od 7 rano do 17). Po powrocie do domu, mimo zmęczenia, musiał jeszcze odrabiać lekcje.

Nauczycielki krytykowały chłopca w obecności innych dzieci, okazywały mu lekceważenie, upokarzając go. Za najdrobniejsze „przewinienie” dostawał uwagi. Rodzice byli często wzywani do szkoły. Jego agresywne zachowania kwalifikowano jako przejaw złego wychowania, nieprzystosowania, złośliwości, działania z premedytacją. Codziennie odbierał sygnały: „coś z tobą jest nie tak!”. W pewnym momencie zapytał mamę: Czy ja jestem głupi, czy nienormalny? Zrozumiał, że jest inny ${ }^{13}$. Coraz częściej pytał o przyczyny wizyt w gabinetach psychologów, psychiatrów, neurologów. Miał świadomość swojej inności, był jednak wobec niej bezradny. Chciał, by go zrozumiano, czy jednak on sam rozumiał siebie...

Łatwo ulegał negatywnym wpływom kolegów. Naśladował ich wulgarne zachowania i słownictwo. Imponowała mu ich siła, bezczelność, łamanie reguł obowiązujących w szkole. Nie pojmował, że ci, których uważa za swoich przyjaciół nie

13 „Świadomość inności pojawia się u dzieci po siódmym roku życia” (Srebnicki 2015: 7). 
są przyjaciółmi, lecz wrogami ${ }^{14}$. Mówił: Z kimś muszę się przyjaźnić. Nie chcę być sam.

A jednak był sam. Dzieci nie chciały stać z nim w parze, nie zapraszały do zabawy ${ }^{15}$, odwiedzania ich $\mathrm{w}$ domu. Funkcjonował na peryferiach klasowej społeczności. Żadne dziecko nie usiadło koło niego w autobusie, którym uczniowie jechali na wycieczkę. Po powrocie do domu, powiedział: Przynajmniej miałem gdzie położyć plecak i nikt do mnie nie gadał. Mogłem spokojnie wyglądać przez okno. Czy był to przykład sposobu działania, o którym wspomniała Joanna Węgrzynowska ze Stowarzyszenia Bliżej Dziecka?

Wiele dzieci ma tendencję, żeby bardzo długo (za długo) ukrywać własne problemy i cierpienie. Zgrywają twardziela, bo nie umieją jeszcze otwarcie rozmawiać o relacjach (...). Myślą, że skoro koledzy ich nie chcą, to znaczy, że nie są fajne, są beznadziejne i nie chcą, żeby to upokorzenie jeszcze zauważyła pani, mama, tato (Poza stadem... 2015: 21).

Po ukończeniu II klasy Krzyś pojechał na kolonie. Tam również doświadczył przemocy ze strony rówieśników (zabieranie zabawek, publiczne zarzucanie mu kłamstwa, gdy tłumaczył, że zabawki są jego własnością, celowe zniszczenie ulubionej maskotki). Kiedy mama spytała, czy powiedział o tym wychowawczyni, usłyszała: Po co? I tak żaden dorosły nie stanie po mojej stronie! Gorzka lekcja, mająca z pewnością wpływ na sposób widzenia rzeczywistości przez dziecko, własnego miejsca w społeczeństwie i stosunek do ludzi.

Niewiele osób zdaje sobie zapewne sprawę z tego, jak ważne dla dziecka jest „uczuciowe wsparcie”. Jego utrata może „prowadzi[ć] (...) do rezygnacji z życia, do zgody na śmierć, ponieważ nie ma ono nikogo, dla kogo mogłoby żyć" (Cyrulnik 2011: 20)16. Na szczęście Krzyś otrzymał wsparcie od rodziców ${ }^{17}$, a w którymś momencie także od niektórych nauczycieli i rówieśników.

Wprawdzie „rolą pedagog[ów] jest pomóc dzieciom w klasie dostrzec mocne, fajne strony (...) odrzuconego"18 (Poza stadem... 2015: 22), wielu z nich jednak nie zauważa problemu, nie chce lub nie potrafi pomóc dziecku (tamże: 20) ${ }^{19}$. Nierzadko sami nauczyciele przyczyniają się do ugruntowania krzywdzącej dla ucznia opinii, mającej związek z jego innością, stygmatyzującej go, utrudniającej mu (uniemożli-

\footnotetext{
14 Zastanawiająca była jego „odporność” na pozytywne wzorce. Naśladowanie ich było znacznie trudniejsze, przede wszystkim jednak wydawało się mniej interesujące.

${ }^{15}$ Czy umiałby się z nimi bawić, podporządkować się ustanowionym przez nie regułom, czy narzucałby własne, domagając się posłuchu?

${ }^{16}$ Autor powołuje się na badania René Spitza, dotyczące „spustoszenia poczynione[go] przez zaniedbania emocjonalne" (Cyrulnik 2011: 20, przyp. 8.).

${ }^{17}$ Pierwszym krokiem było uznanie problemu i podjęcie decyzji o szukaniu pomocy.

${ }^{18}$ Autorką tych słów jest J. Węgrzynowska.

${ }^{19} \mathrm{~J}$. Węgrzynowska stwierdziła, że wielu nauczycieli „nie jest uwrażliwionych na (...) problem” przemocy psychicznej, „bagatelizuje [też] sygnały alarmowe lub w ogóle ich nie dostrzega” (Poza stadem... 2015: 20-21).
} 
wiającej) bezpieczne i przyjazne funkcjonowanie w środowisku szkolnym. Nie biorą odpowiedzialności za relacje, atmosferę w klasie, „wycofują się z wychowywania” (tamże) ${ }^{20}$. Tak było w przypadku Krzysia, kiedy chodził do „zerówki”, w klasach I-III i na początku klasy IV.

Kilka lat temu od jednej z nauczycielek usłyszałam, że szkoła nie jest od wychowywania, naprawiania błędów popełnionych przez rodziców, tylko od nauczania. Czy takie założenie nie jest równoznaczne z przyzwoleniem na przemoc i jej skutki, odrzucenie „odmieńców”, konflikty w klasie? Zdaniem Marii Mach, „zarzuc[enie] wychowania”, będące „jednym z największych problemów szkoły”, jest „pozorne”; „(...) praca wychowawcza wre, nie da się jej nie wykonywać, jeśli się przebywa z dziećmi. (...) To idzie poprzez przykład. A szkole się wydaje, że zostawi wychowanie rodzicom i skupi się na wlewaniu oleju do głowy” (Klasa ziewających... 2016: 34).

W polskich szkołach obowiązuje bezwzględna rywalizacja. „Nie uczymy dzieci, że siła jest w zespole (...) w naszej szkole wciąż najważniejsze jest: lepszy od kolegów czy gorszy od kolegów. Lepszy, to lepiej zda test, pójdzie do najlepszego gimnazjum, itd." (Poza stadem... 2015: 23) 21. Polska nie jest wyjątkiem. W wielu krajach szkoła jest terenem rywalizacji. Walka o najlepsze oceny staje się ważniejsza od zdobywania wiedzy (Andreoli 2009: 233). System edukacyjny „nie szanuje inności i nie pozostawia nawet marginesu wolności koniecznego dla osobistych poszukiwań i odkryć" (tamże: 134). Funkcjonuje podobnie jak dom, w którym nie bierze się pod uwagę „najgłębsz[ych] pragnie[ń] i potrzeb” dziecka (tamże: 134135). Taki dom znał Krzyś. Od najmłodszych lat był świadkiem konfliktów między rodzicami, wybuchów gniewu ojca, krytyki, jakiej mężczyzna ten nie szczędził najbliższym. Słyszał, że jest przyczyną złej atmosfery w domu, nieporozumień, napięć. Był często karany, upokarzany. Narastało w nim poczucie winy i lęku. Sytuacja zaczęła się zmieniać, gdy rodzice dostrzegli, że chłopiec wymaga specjalistycznej opieki i pomocy. Do podjęcia intensywnych poszukiwań odpowiedzi na pytanie, co dzieje się z ich dzieckiem i jak można mu pomóc zmusiły ich sygnały płynące ze szkoły. Mama Krzysia zaangażowała się natychmiast, w przypadku ojca trwało to dłużej. Było mu trudno przyjąć prawdę o dziecku, które nie spełniało jego oczekiwań, o złych relacjach rodzinnych, konieczności naprawienia błędów wychowawczych i zmiany domowej atmosfery, by choć tutaj chłopiec mógł odetchnąć, uspokoić się, wyciszyć, by nie czuł się odrzucony.

Vittorino Andreoli stwierdził, że dziecko odrzucone

jest ofiarą systemu, który wszędzie tworzy hierarchie - w szkole wśród uczniów, w domu między rodzeństwem. Takiego dziecka nie bierze się

\footnotetext{
20 „Ucieczka od wychowania” nie jest zjawiskiem charakterystycznym jedynie dla współczesnego systemu oświaty. Występowało ono w okresie PRL, aczkolwiek - moim zdaniem - w mniejszym stopniu niż obecnie, i miało inne przyczyny (więcej na ten temat patrz: Bujak 2001: 136-138).

${ }^{21}$ Rywalizację popierają nauczyciele i rodzice myślący przede wszystkim o własnych dzieciach, niedostrzegający problemów uczniów odrzuconych przez rówieśników i dorosłych (Poza stadem... 2015: 23). Z takimi osobami często stykał się Krzyś i jego rodzice.
} 
pod uwagę i wyłącza się je z grupy. (...). Jest [ono] ofiarą społeczeństwa, tworzącego zasady, na mocy których jednych wyklucza, a drugich nagradza, zamiast popierać tworzenie grup wzajemnej pomocy, w których wszyscy mają rolę na miarę posiadanych talentów i nawzajem się szanują (Andreoli 2009: 129).

Cytowany autor podkreślił, że żyjemy w czasach zdominowanych przez bezwzględną rywalizację, w „kulturze wrogości”. Jej przejawem są m.in. relacje międzyludzkie (tamże: 42). Kulturę tę cechuje nieustanna walka o wszystko i ze wszystkimi, brak współczucia i solidarności, obojętność, nieczułość, indywidualizm, podejrzliwość, wrogość, poniżanie innych, a nawet radość z zadanego innym cierpienia (tamże: 93). Przeciwieństwem „kultury wrogości” jest „kultura solidarności”, więzi (tamże: 43). Andrzej Szahaj nazwał kulturę zdominowaną przez rywalizację, walkę o przetrwanie i zachowania mające poniżyć drugiego człowieka, „kulturą upokarzania" (Szahaj 2012; patrz też: Bożeński 2000; Kabzińska 2013; Rydlewski 2013; Wadowski 2011). Wrogość i upokorzenie są ściśle związane z „kulturą «odrzucenia»" (Ojciec Święty Franciszek 2014: 53):

Nie chodzi już tylko o zjawisko wyzysku i ucisku, ale o coś nowego; przez wykluczenie zraniona jest w samej swej istocie przynależność do społeczeństwa, w którym człowiek żyje. (...) Wykluczeni nie są „wyzyskiwani”, ale są odrzuceni, są „niepotrzebnymi resztkami”. (...) Dzisiaj wszystko poddane jest prawom rywalizacji i prawu silniejszego, gdzie mocny pożera słabszego (tamże).

Z odrzuceniem stykają się nie tylko ludzie „zbędni” w kategoriach ekonomicznych, nieprzydatni jako konsumenci i producenci, lecz wszyscy, którzy przegrywają we wszechobecnej rywalizacji, niepasujący do obowiązującego (dominującego) wzoru kulturowego, „odmieńcy”, nieradzący sobie z rzeczywistością i stawianymi przez nią wymogami. „Człowiek współczesny jest upokorzony presją na określony tryb życia; jeśli takiego stylu życia nie podejmie, zostanie zmarginalizowany lub nawet wyrzucony poza «normalne społeczeństwo»" (Wadowski 2011: 262).

Pewien psycholog powiedział mi, że któregoś dnia z okna swego gabinetu obserwował wrony. Młode ptaki walczyły ze sobą, wyraźnie o coś się sprzeczały (może próbowały określić swoje miejsce w grupie? - pomyślałam). Rodzice obserwowali je z boku, czekając, aż dzieci same rozwiążą problem. Czy tak samo maja postępować ludzie? - zapytałam. Psycholog odpowiedział: Tak! Zwierzęta sq mądre. Trzeba się od nich uczyć. Może więc słusznie czynią nauczyciele, którzy nie pomagają dzieciom w rozwiązywaniu konfliktów, nie reagują na przemoc, nawet jeśli może ona zakończyć się tragicznie? Może z pomocą spieszą jedynie nadwrażliwi, obdarzeni empatią, współczuciem, odbierający sygnały niedostrzegalne dla innych, jak nauczycielka, która zauważyła Jaya, stojącego samotnie na szkolnym dziedzińcu... 
Krzyś coraz częściej skarżył się na bóle brzucha, nudności, bezsenność, brak apetytu. Codziennie powtarzał, że nienawidzi szkoły, bał się spotkań z kolegami, którzy mu dokuczali, sprawiali, że wciąż musiał być czujny, uważać, by ktoś go nie popchnął, nie uderzył, nie przewrócił. Bał się nie tylko kolegów z klasy, ale też starszych uczniów, którzy byli wobec niego agresywni.

Osobą, która okazywała chłopcu życzliwość była jedna z woźnych. Zauważyła, że jest samotny, że dzieci mu dokuczają. Uśmiechała się do niego, dodawała otuchy, czasem pogłaskała po głowie, powiedziała dobre słowo. Była wrażliwym, ciepłym Człowiekiem, jak nauczycielka, którą spotkał Jay. Nie mogła jednak mu pomóc, zmienić jego sytuacji.

W jednym z licznych testów, jakie musiały rozwiązywać dzieci, znalazło się pytanie: „Do kogo byś się zwrócił w razie problemów w szkole?”, Krzyś napisał: „Do pani woźnej”. Odpowiedź nie została uznana. Zapewne nie przewidziano jej w „kluczu” do testów. Nie po raz pierwszy chłopiec przekonał się, że w szkole nie ma miejsca na samodzielne myślenie, oryginalność, indywidualizm.

Kłopoty szkolne Krzysia nasiliły się w IV klasie. Pojawili się nowi nauczyciele (każdy przedmiot prowadziła inna osoba). Przybywało uwag w dzienniczku. Chłopiec stawał się coraz bardziej agresywny, wulgarny, hałaśliwy. Nie panował nad emocjami. Coraz gorzej znosił niepowodzenia. Coraz częstsze były bójki z kolegami, zaczepki z ich strony, groźby. Pojawiły się namowy do ucieczki z lekcji, kradzieży w sklepach, bicia młodszych dzieci, palenia papierosów.

Rodzice wymogli na pani dyrektor zgodę na przeniesienie syna do równoległej klasy. Dyrektorka nieoczekiwanie wyraziła zgodę. Decyzja o zmianie klasy okazała się przełomem. Nowa wychowawczyni otoczyła chłopca opieką. Często rozmawiała z jego rodzicami, starając się zrozumieć problemy, była życzliwa, otwarta, sympatyczna. Wciąż jednak nie było diagnozy! Skłaniano się ku ADHD, nie zostało to jednak stwierdzone na piśmie 22 .

W kolejnych opiniach wystawianych przez specjalistów znajdowały się zalecenia dla nauczycieli, jak należy traktować dziecko, które pracuje wolniej niż inni uczniowie, odmawia wykonania poleceń, chodzi po klasie, rozmawia, ma trudności z koncentracją, szybko się męczy i nudzi. Nie wszyscy nauczyciele jednak zapoznali się z tymi opiniami, nie wszyscy też kierowali się zawartymi w nich wskazówkami. Pod koniec IV klasy udało się zatrudnić osobę, która pracowała z Krzysiem na lekcjach, pomagała mu zrozumieć polecenia, relacje między nią a chłopcem były jednak napięte. Nie darzyli się sympatią.

Zmiana klasy pokazała, jak wiele zależy od ludzi, ich postawy, serca, zrozumienia, otwarcia na drugiego człowieka, od środowiska społecznego, w jakim przebywa dziecko. W nowej klasie nie było przemocy, grupy chłopców terroryzujących inne dzieci i nauczycielki obojętnej (bezradnej?) wobec tego faktu. Nie było też

\footnotetext{
22 Żaden z psychologów, psychiatrów i neurologów nie zasugerował, że Krzyś może być dzieckiem nadwrażliwym.
} 
skarg rodziców uczniów na Krzysia. W poprzedniej klasie skarżyli na niego m.in. rodzice tych, którzy mu najbardziej dokuczali, zawsze popierając własne pociechy i wierząc bezgranicznie w każdą z ich opowieści. Twierdzili, że mają zaufanie do swoich dzieci, odmawiali jednak tego prawa rodzicom Krzysia.

Po zmianie klasy okazało się, że chłopiec potrafi funkcjonować w grupie. Część dzieci pomagała mu. Niektóre denerwowały jego zachowania, nie były jednak wobec niego agresywne, nie wyśmiewały go. Nie czuł się też osamotniony. Miał przede wszystkim oparcie w wychowawczyni, znalazł też kolegów, z którymi potrafił się bawić (najczęściej grali w piłkę i gry komputerowe). Rozmawiali o sporcie, klockach lego, filmach, Internecie, sprawach szkolnych i rodzinnych.

Kiedy Krzyś przyszedł do nowej klasy, wychowawczyni zachęciła jego mamę, by opowiedziała o problemach syna podczas zebrania rodziców. Od wielu z nich usłyszała słowa wsparcia, obietnicę pomocy. Rozpłakała się. Przyznała, że nigdy wcześniej nie spotkała się ze zrozumieniem, życzliwością, serdecznością, w stosunku do niej i jej dziecka. Podczas klasowej Wigilii rodzice uczniów podchodzili do Krzysia i jego mamy, żeby podzielić się opłatkiem. Niektórzy uśmiechali się, przytulali oboje. Kobieta miała łzy w oczach.

Chłopiec był bystrym obserwatorem, ciekawym świata, ludzi. Lubił kino, teatr, filmy przyrodnicze, interesował się historią, informatyką, chętnie odwiedzał muzea. Zadawał mnóstwo dociekliwych pytań, chcąc zrozumieć świat. Nurtowało go wiele problemów. Próbował o nich rozmawiać z nauczycielami, nie było jednak na to czasu, zwłaszcza podczas lekcji. Program szkolny nudził chłopca i przerażał swoim ogromem. Był trudny, przeładowany, nieciekawy. Nie lubił rozwiązywania testów, nie mógł się wówczas wypowiedzieć, podzielić własnymi przemyśleniami. Ważniejsza od dociekania, formułowania pytań i szukania odpowiedzi na nie była szczegółowa wiedza pamięciowa. Chłopiec był znużony nadmiarem informacji przekazywanych przez nauczycieli, szybkim tempem pracy, ciągłym nadrabianiem zaległości, brakiem sukcesów na miarę wysiłku, jaki wkładał w naukę. Ogromną pracę wykonywali rodzice, zwłaszcza mama, która każdego dnia - po powrocie z pracy - odrabiała z nim lekcje, mimo potężnego zmęczenia obowiązkami zawodowymi i domowymi oraz własnych problemów ze zdrowiem. Najtrudniejszą do pokonania barierą okazały się relacje z większością nauczycieli. Brak życzliwości, chęci pomocy, obojętność, niezrozumienie.

Wiem, że nauczyciele muszą przede wszystkim realizować (przeładowany) program, nie mają czasu na wnikanie w problemy dzieci, rozmowy $\mathrm{z}$ nimi, są bezradni wobec negatywnych wzorów zachowań przekazywanych przez rodziców i media, powielanych przez odbiorców w różnym wieku. Czy jednak można tym usprawiedliwiać brak życzliwości, dołączenie do grupy stygmatyzującej „innych”, skazującej ich na odrzucenie? Dlaczego dziecko, które dostaje złe oceny, nagle - po zmianie nauczyciela - otrzymuje stopnie bardzo dobre i celujące? Dlaczego nowy nauczyciel potrafi je zmotywować, nagrodzić, zauważyć jego wysiłki, inteligencję? Tak było w przypadku Krzysia. Szkoda, że nauczyciele, którzy go doceniali, najczę- 
ściej przychodzili na zastępstwo. Kiedy odchodzili, znów pojawiały się słabe oceny, uwagi i problemy w relacjach międzyludzkich.

Krzyś przekonał się, że szkoła

jest znacznie mniej nastawion[a] na wykrywanie i rozbudzanie pasji, wzmacnianie indywidualności, wysłuchiwanie pytań uczniów, a bardziej na diagnozowanie odchyleń od normy i bezwzględne ich korygowanie. Czy to w sposobie pisania literek, czy tempie pracy, czy przedmiocie zainteresowań. (...) (Klasa ziewających... 2016: 34).

Nie bierze pod uwagę, że „uczeń powinien być miarą sam dla siebie, ponieważ dojrzewamy nielinearnie. To sama praca ma sprawiać dzieciom przyjemność. (...)” (tamże; por. Zniewolony umysł... 2016: 11). Obowiązuje tu przekaz wiedzy metodą wykładu (Klasa ziewających... 2016: 34). Maria Mach przypomniała, że

Sokrates zachęcał do myślenia i uczył formułować pytania. Umiejętność dobrego sformułowania pytania to dziś jedna z najistotniejszych rzeczy w nauce. Nieraz trudniejsza niż znalezienie odpowiedzi. Tymczasem szkoła nie pyta, ale odpytuje. (...) w takiej sytuacji mózg o wiele mniej się uaktywnia, niż gdy naprawdę razem szukamy odpowiedzi na jakieś dręczące nas pytanie. (...) dochodzą emocje, ekscytacja. Bycie odpytywanym nie jest ekscytujące, jest nudne, albo upokarzające, więc mózg śpi. (...) (tamże).

Szkoła nie odpowiada na „potrzeb[ę] umiejętności myślenia (...) [i] zadawania pytań” (Szkoła szczęśliwszych... 2016: 30), przede wszystkim tych o charakterze egzystencjalnym, „o sens życia czy poczucie winy” (tamże) ${ }^{23}$. Nie ma tu miejsca na dialog, „krytyczn[y] namysł” (tamże: 31). Jest nuda i lęk; „uczy się w niej wszystkich tego samego, w tym samym czasie, w taki sam sposób, a na dodatek po to, żeby potem tę wiedzę sprawdzać" (tamże; por. Zniewolony umysł... 2016: 11).

W TVP Kultura 28 maja 2016 r. obejrzałam duński film dokumentalny pt. Dzieci $w$ czasach $A D H D$, poświęcony realizacji programu mającego pomóc uczniom borykającym się z tą dolegliwością. Ich liczba lawinowo rośnie. Może to być spowodowane coraz większą ilością bodźców w otoczeniu, „zwiększoną stymulacją” (Zeff 2008: 66). Osoby, u których stwierdzono ADHD, są leczone środkami mogącymi mieć „niezliczone efekty uboczne” (tamże) ${ }^{24}$. Zdaniem Zeffa leczenie „«nadaktywn[ych]» dzieci” nie byłoby konieczne, gdyby środowisko, w którym żyją, było środowiskiem „naturalnym i wolnym od elektronicznych urządzeń" (tamże). Ponieważ wciąż przybywa tego typu urządzeń, można się spodziewać dalszego wzrostu liczby dzieci z ADHD (tamże).

\footnotetext{
${ }^{23}$ Wszechobecne testy i brak indywidualnego podejścia do ucznia nie sprzyjają logicznemu myśleniu, umiejętności formułowania pytań i poszukiwania odpowiedzi na nie.

${ }^{24}$ Czy rodzice są tego świadomi? Czy informują ich o tym lekarze?
} 
W notce zawierającej informacje o wspomnianym przeze mnie filmie czytamy:

ADHD to zespół nadpobudliwości psychoruchowej z deficytem uwagi. Typowe objawy tego zaburzenia to nadmierna ruchliwość, brak koncentracji i zaburzenia emocjonalne. Szacuje się, że w Polsce dotyka ono 80 tys. dzieci, co oznacza, że cierpi na nie 1 na 100 uczniów podstawówki. Problem jest obecny na całym świecie. W filmie (...) poznamy mieszkańców Danii. Marino, Martine i Victor mają zdiagnozowane ADHD. Ich historia pozwala poznać problemy, z którymi na co dzień muszą się zmagać takie dzieci. Rodzice szukają ratunku w farmakologii, ale lekarze są bezradni, bo to nie przynosi spodziewanych efektów. Nadzieją może być specjalny program utworzony w jednej z duńskich szkół, który koncentruje się na indywidualnych problemach dziecka. We współpracy z rodzicami i terapeutami jest dopasowywany pod kątem bieżących potrzeb. Dzieci uczą się kontrolować swoje uczucia i zachowania (KZ 2016).

Twórcy programu udowodnili, że dzieciom z ADHD można pomóc bez stosowania farmakologii. Opinie specjalistów są jednak podzielone (patrz np. Kossobudzka 2015).

Realizacja programu opracowanego przez duńskich specjalistów zapewne wymaga dużych nakładów ${ }^{25}$, zatrudnienia dodatkowych osób, które potrafią rozmawiać z dziećmi, wsłuchać się w ich głosy, nawiązać relacje oparte na zaufaniu, przede wszystkim jednak rozumieją, czym jest ADHD. Niektórzy terapeuci znają ten problem z własnego życia26. Mówią o tym uczniom, dzielą się swymi doświadczeniami, stając się w ich oczach osobami bardziej wiarygodnymi, bliskimi. Łatwiej im wejść w świat dziecka, znaleźć z nim wspólny język, pomóc. Wspólnota doświadczeń z pewnością sprzyja nawiązaniu kontaktu, porozumieniu, nasuwa się jednak pytanie, czy bez niej nie można okazać życzliwości osobie odrzuconej przez grupę, mającej trudności z funkcjonowaniem w niej, borykającej się z problemami. Czy nie można jej wysłuchać i postarać się zrozumieć? Czy rzeczywiście przykład „starych wron" jest godny naśladowania?

Sądzę, że to, czego nauczyli się uczestnicy programu, o którym opowiadają twórcy filmu Dzieci w czasach $A D H D$, pomoże im lepiej funkcjonować w grupie rówieśniczej i - generalnie - w społeczeństwie, radzić sobie z emocjami, koncentracją. Rodzi się jednak pytanie, ile osób skorzystało z tego programu, czy zrealizowano go tylko w jednej duńskiej, szkole, czy podobne programy, wymagające nakładów i indywidualnego podejścia do dziecka, są realizowane w Polsce.

W jednej z audycji radiowych ${ }^{27}$ podano przykłady programów szkolnych, stanowiących alternatywę dla wszechobecnej rywalizacji, konkurencji, mających uczyć

\footnotetext{
25 Łatwiej zaordynować dziecku środki uspokajające, za które płacą rodzice.

26 Takie osoby uczestniczyły w realizacji programu, o którym jest mowa we wspomnianym filmie.

27 Program Pierwszy Polskiego Radia, 24 stycznia 2013 r., godz. 21.00, Studio Reportażu i Dokumentu.
} 
dzieci współpracy, odpowiedzialności za wspólne dobro, dążenia do wspólnego celu. Jest w nich miejsce na indywidualność oraz głębokie więzi między uczniami i nauczycielami ${ }^{28}$. Podczas dyskusji z udziałem słuchaczy padło fundamentalne pytanie: Do jakiego społeczeństwa przygotowuje szkoła, w której realizowane są wspomniane programy? Pozostało ono bez odpowiedzi.

Pojawia się również pytanie dlaczego polska szkoła masowa miałaby podejmować walkę z przemocą, upokorzeniem, bezwzględną rywalizacją, „kulturą wrogości" i odrzucenia, skoro funkcjonuje w systemie promującym takie zachowania, utrwala je, będąc istotnym elementem tego systemu (więcej patrz: Kabzińska 2013: 195-196). Stykamy się w niej nie tylko ze zjawiskiem upokarzania dzieci z ubogich rodzin przez uczniów mających zamożnych rodziców (Szahaj 2012: 42). Upokarzani są wszyscy „odmieńcy”, w tym - np. osoby kreatywne, myślące, pragnące zdobywać wiedzę, indywidualiści. Stają się one ofiarą zarówno rówieśników, jak również niektórych nauczycieli, nagradzających przebiegłość, koniunkturalizm, cynizm, kłamstwo, przyswajanie wiedzy bez zrozumienia (Firlej 2011: 97-104; patrz też Potulicka, Rutkowiak 2010; Żakowski 2013a, 2013b).

Szkoła „(...) ma tendencję do wiecznego zasypywania dołów zamiast do dostrzegania szczytów - wysp dziecięcych zainteresowań - i budowania nad nimi mostów (...)" (Kossobudzka 2015: 5) ${ }^{29}$.

Dorośli (...) [zazwyczaj dążą] do równania wszystkich dzieci do pewnego poziomu. Dziecko jest według nich ambitne, gdy potrafi siedzieć i uczyć się materiału, który go mało interesuje. Chwalimy (...) dzieci wkuwające formułki, przegapiając ich inne zdolności czy możliwości (tamże) ${ }^{30}$.

Nasze szkoły najczęściej są miejscem, w którym nauczyciele „bazuj[ą] na deficytach uczniów. Szybciej powie[dzą], czego dziecko nie potrafi, wskaż[ą] brak, niż pochwal[ą] za postęp i za to, co dziecko już wie (...)” (mw/ja 2016: 26) ${ }^{31}$. „Ciągle jesteśmy krajem, w którym cieszymy się z wykazywania, że ktoś jest gorszy. I dlatego w szkole nie koncentrujemy się na tym, jak odkryć pokłady złota w osobowości dziecka, tylko udowadniamy, czego nie umie" (Zniewolony umysł... 2016: 11). Tymczasem

[d]obra szkoła to nie ta, która ma uczniów wykazujących się największymi osiągnięciami w skali bezwzględnej. Tylko ta, w której uczniowie robią największe postępy w stosunku do tego, z czym przyszli. Być lepszym, od siebie samego - to jest sukces dostępny dla każdego (Klasa ziewających... 2016: 35).

\footnotetext{
${ }^{28}$ Takie programy są wdrażane w niektórych polskich placówkach szkolnych.

${ }^{29}$ Autorka cytuje wypowiedź psychoterapeutki Beaty Chrzanowskiej-Pietraszuk.

${ }^{30}$ Autorem tych słów jest psychoterapeuta Tomasz Srebnicki.

31 Autorką tych słów jest Joanna Okuniewska (na ten temat patrz też np. Kossobudzka 2015; Poza stadem... 2015).
} 
Nie wiem, jak potoczyły się dalsze losy Krzysia. Czy sformułowano wreszcie diagnozę? Czy miało to wpływ na jego codzienne funkcjonowanie w szkole, w rodzinie? Moja koleżanka nie żyje. Jej siostra, siostrzenica i Krzyś mieszkają w innym mieście. Nie znam ich adresu, numeru telefonu, nie mam z nimi kontaktu. Pewnie nawet nie wiedzą o moim istnieniu i o tym, że stali się dla mnie kimś ważnym.

Nigdy nie poznam Krzysia osobiście. Nie usłyszę jego opowieści. Nie usłyszę też relacji osób, wśród których przebywał. Nie porównam ich treści. Nie zrozumiem, dlaczego musiał czekać kilka lat na diagnozę. Dlaczego tak niewiele osób okazało mu życzliwość, zainteresowanie jego problemami, usłyszało wołanie o pomoc, dostrzegło jego wysiłki, potrafiło je nagrodzić dobrymi ocenami, zdopingować do dalszej pracy.

Krzyś powinien już skończyć szkołę podstawową. Czy dostał się do gimnazjum? Jak sobie radzi w nowym otoczeniu? Jak traktują go nauczyciele? Czy wrócił koszmar odrzucenia, doświadczenia przemocy fizycznej i psychicznej, niezrozumienia, osamotnienia? Czy spotkał osoby, które chcą i potrafią mu pomóc? Nigdy się tego nie dowiem.

Nie znam wielu szczegółów dotyczących zachowań Krzysia. Nie znała ich również moja koleżanka. Nie mam dostępu do dokumentacji, opinii, zaleceń, nie mogę porozmawiać z ich autorami. Nie mogę spojrzeć na chłopca z perspektywy jego nauczycieli, kolegów, specjalistów, do których trafiał, którzy tak długo nie potrafili (nie chcieli?) postawić diagnozy. Jak zmieniłoby się życie Krzysia i jego rodziców, gdyby diagnozę sformułowano na początku jego pobytu w szkole, gdyby trafił do klasy integracyjnej?

Mogę sobie wyobrazić, w jak trudnej sytuacji byli nauczyciele, którym chłopiec przeszkadzał swoim zachowaniem. Denerwował ich, rozpraszał, utrudniał prowadzenie lekcji. Może zbyt wiele od nich wymagałam, oczekując, że porozmawiają z dzieckiem, zrozumieją jego problemy, będą je wspierać, spróbują pomóc. Czasem myślę: gdyby na miejscu wychowawczyni (w „zerówce”, w klasach I-III i na początku klasy IV) była inna osoba, bardziej współczująca, wrażliwa, obdarzona empatią... Ale jej nie było.

Specjaliści w poradni szkolnej sugerowali, by Krzyś powtórzył „zerówkę”, rodzice jednak postanowili inaczej. Czy ich decyzja była błędna? Gdyby rozpoczął naukę w I klasie rok później niż inne dzieci z jego rocznika miałby więcej czasu na dostosowanie się do wymogów szkolnych, nie spotkałby też nauczycielki, z którą nie można było się porozumieć, ani dzieci, które mu dokuczały, czy jednak takie roczne opóźnienie spowodowałoby radykalną zmianę jego zachowań? Jak potoczyłyby się losy Krzysia, gdyby trafił do placówki stanowiącej alternatywę dla szkoły masowej? ${ }^{32}$

32 Krzyś nazywał ją „szkołą przetrwania” albo „hodowlą robotów”. 


\section{Komu są potrzebne alternatywne modele szkoły?}

Myślę o tym, dlaczego ludzie tak często - świadomie lub nieświadomie - zadają sobie rany. Dlaczego szkoła jest miejscem pełnym agresji, przemocy wobec słabszych, „innych”33. Sądzę, że jest ona miniaturą społeczeństwa, odzwierciedlającą rzeczywistość, w której żyjemy, w której najtrudniej jest słabym, bezradnym, przegrywającym w rywalizacji, różnego rodzaju „odmieńcom”. Stanowi też istotny element mechanizmu selekcji, w której wygrywają najlepiej przygotowani do życia zdominowanego przez kulturę upokarzania, wrogości, odrzucenia. Dla współczesnego społeczeństwa „priorytetem są kasa i posada. Te wartości promuje szkoła. Ustawia uczniów w indywidualnym wyścigu po pozycję, prestiż i pieniądze" (Klasa ziewających... 2016: 34). Wprawdzie „[d]ziecko nie powinno być zmuszane do przyjmowania perspektywy dorosłych: długoterminowa inwestycja, start, wynik (...)" (tamże: 35$)^{34}, \mathrm{w}$ rzeczywistości jednak od najmłodszych lat styka się ono z prawami rządzącymi społeczeństwem. Współczesny świat mówi: „daj sobie spokój z myśleniem. (...) Ludzie są przygotowani do pełnienia jednej roli - konsumenta. W tym świecie realne jest tylko to, co w jakiś sposób dobrze służy wzrostowi PKB. Szkoła też. (...)” (Szkoła szczęśliwszych... 2016: 31). Coraz częściej mówi się o tym, „by mocniej związać edukację z rynkiem, uczynić z niej element rynku” (tamże) ${ }^{35}$.

Pracodawcy „(...) mówią (...) [o] potrzeb[ie] absolwentów umiejących pracować zespołowo, a nie w pojedynkę" (Klasa ziewających... 2016: 34). Szkoła jednak nie uczy tego rodzaju zachowań (tamże; por. Andreoli 2009: 93). Należy też zauważyć, że w środowiskach zawodowych jest coraz mniej miejsca na bliskie relacje koleżeńskie, bezpośrednią komunikację, ciepło więzi międzyludzkich, wolność ekspresji. Obowiązuje „nowy porządek”, który cechuje: chłód, profesjonalizm, odpersonalizowanie, kontrola nad zachowaniami pracowników, ograniczenie różnorodności. Znamienne jest przejście od przekonania: „w pracy ważne są relacje”; „człowiek jest najważniejszy” do: „w pracy ważne jest wypełnianie zadań”; „w organizacji najważniejszy jest rozwój" (Jagiełło 2012: 174). Pracownicy muszą się dostosować do

\footnotetext{
33 O skali tego problemu w Polsce świadczą np. badania przeprowadzone w 2015 r. przez Instytut Badań Edukacyjnych (Raport metodologiczny... 2015). Uwzględniono w nich m.in. zjawisko, jakim jest klimat szkoły i klasy. „Obejmuj[e] [ono] m.in. relacje między nauczycielami a uczniami, relacje w gronie uczniowskim, poczucie bezpieczeństwa uczniów, relacje w gronie nauczycielskim oraz między nauczycielami a dyrektorem, a także takie specyficzne cechy szkoły, jak poziom rywalizacji, zasady i wymagania” (tamże: 5). Bardzo ważne jest również m.in. „wsparcie uzyskiwane przez uczniów ze strony nauczycieli” (tamże). Twórcy Raportu... powołali się na „zagraniczne badania [które] pokazują związki klimatu szkoły i klasy m.in. z agresją i przemocą szkolną, zachowaniami ryzykownymi, wynikami w nauce czy samopoczuciem fizycznym i psychicznym uczniów" (tamże). Zjawisko, jakim jest klimat szkół i klas, nie było dotychczas u nas przedmiotem szczegółowych badań (tamże).

${ }^{34}$ Dzieci powinny „mieć prawo do słomianego zapału. Pomyłek. Zmieniania zainteresowań”, „[ż]eby w przyszłości wiedzieć, czym chc[ą] się zajmować” (Klasa ziewających... 2016: 35; por. Zniewolony umysł... 2016: 11).

35 Robert Kwaśnica zauważył, że „dobro oznacza dziś korzyść, a zło - stratę” (Szkoła szczęśliwszych... 2016: 30).
} 
obowiązujących reguł. Umiejętność pracy w zespole ma służyć realizacji określonych zadań, przynoszących wymierne korzyści. Zatrudnianie niektórych kategorii „odmieńców” jest uwarunkowane ich zdolnościami, ocenianymi pod kątem efektów, jakie mogą przynieść pracodawcom (ANS 2016: 73). Pracę, jak sądzę, znajdują nieliczni. Większość nie ma do niej dostępu, powiększając grupę „odrzuconych”, zbędnych.

Zastanawiam się, dlaczego jedynie 4-5 procent rodziców i nauczycieli jest zainteresowanych szkołą holistyczną, w której nie ma nudy i lęku, w której podchodzi się do dziecka indywidualnie, rozwijając jego zdolności, pobudza się refleksyjność, „przygotowuje wrażliwość dyskursywną, zdolność do dialogu, krytycznego namysłu” (Szkoła szczęśliwszych... 2016: 30-31). Może większość nie chce zmian? Może nie jest jej potrzebna „zdoln[ość] do krytycznego czytania przekazu kulturowego, mniej[sza] podatn[ość] na modę, manipulację, ideologie, wpływ różnych uzdrowicieli społecznych. (...)" (tamże: 31)? R. Kwaśnica stwierdził, że absolwenci szkoły holistycznej mogą być „trochę szczęśliwsi” (tamże). Podobnie jak w przypadku innych modeli szkoły, będących alternatywą dla szkoły masowej, tę drogę do szczęścia aprobuje jedynie niewielka grupa osób. Dla większości szczęściem jest konsumpcja, „kasa i posada”, życie niewymagające refleksji, formułowania pytań, zwłaszcza egzystencjalnych, opanowania sztuki dialogu, dlaczego więc mieliby pragnąć zmian. Zdaniem Bogusława Śliwerskiego, w polskiej szkole „tylko 30 proc. nauczycieli chciałoby (...) [dziecięce] umysły uwalniać" (Zniewolony umysł... 2016: 11). „[M]niej więcej 40 proc. to rzemieślnicy - przykładni, ale niezbyt twórczy. Pozostali to tacy, którzy leczą kompleksy, bo mają władzę" (tamże) ${ }^{36}$.

Wydaje mi się, że istnieje społeczne przyzwolenie na przemoc w szkole, upokarzanie „odmieńców”, „klasowych głupków”. Są oczywiście wspaniali nauczyciele, świetne programy edukacyjne, klasy i szkoły, w których klimat sprzyja spokojnej nauce, bezpieczeństwu, kreatywności, nawiązywaniu głębokich relacji, mamy tu jednak do czynienia z wyjątkami. Zdaniem Józefa Kozieleckiego, „system szkolny zalewają fale NiL - nudy i lęku. Nudy tych ponadprzeciętnie uzdolnionych i lęku tych, którzy mają jakieś deficyty" (Zniewolony umysł... 2016: 11).

Niedawno przeczytałam następujące informacje o szkolnictwie w Finlandii.

Edukacja jest tu na najwyższym światowym poziomie. Na Uniwersytecie w Tampere co roku na studia pedagogiczne zgłasza się około 1600 kandydatów, z czego na I rok przyjmuje się tylko 70 studentów. Kandydatów na studia nadal obowiązują egzaminy wstępne: pisemne i ustne. Kto dostanie się na studia i je ukończy, jest wspaniale przygotowany do zawodu pedagoga $^{37}$ (Solarek 2016: 79).

\footnotetext{
${ }^{36}$ Bogusław Śliwerski dobrze ocenił przyjęty w Polsce sposób kształcenia nauczycieli. Stwierdził, że „(...) uczelnie wypuszczają ludzi z wyobraźnią, myślących, wyposażonych w dobre narzędzia (...) [a]le tylko nieliczni trafiają do szkół, gdzie mogą się realizować. Większość - do mini-więzień" (Zniewolony umysł... 2016: 11).

$37 \mathrm{~W}$ artykule, na który się powołuję, brak informacji o wymogach stawianym fińskim pedagogom.
} 
Autorka tych słów była zdumiona, gdy powiedziano jej, że „w jednej ze szkół (...) najlepszy nauczyciel matematyki został oddelegowany do pracy z najsłabszymi uczniami” (tamże). Dowiedziała się również, że „w Finlandii nie ma korepetycji, gdyż nie są potrzebne. Nie ma też świadectw z czerwonym paskiem. Nie ma nadzoru nauczycieli ani hospitacji lekcji, ponieważ dyrektor ma zaufanie do pracowników. A zaufanie - to w Finlandii podstawa" (tamże) ${ }^{38}$. Fińscy

[u]czniowie w szkołach, podobnie jak w domu, chodzą w skarpetkach. Na przerwy - niezależnie od pogody - wychodzą na dwór. Nawet przedszkolaki codziennie przebywają na powietrzu, także w jesienne słoty i mroźne zimowe dni. Każdy uczeń dostaje w szkole bezpłatny obiad (tamże).

W Finlandii istnieje „kilka, kilkanaście elitarnych szkół pedagogicznych” (Szkoła szczęśliwszych... 2016: 31). „Poprzeczka dla kandydatów” ustawiona jest „bardzo wysoko” (tamże). Nauczyciele są „świetn[ie]” wynagradzani, cieszą się też „wysoki[m] status[em] społeczny[m]” (tamże). R. Kwaśnica, zapytany przez Roberta Siewiorka, „dlaczego nie odwołać się do modelu fińskiego (...)”39, nie skorzystać z jego doświadczeń, odparł: „Nie pomyślałem o tym. Może wyszedłem z przekonania, że adresowanie takiego postulatu do państwa nie ma sensu? (...)" (tamże) ${ }^{40}$.

Nie jest, moim zdaniem, przypadkiem, że przyjazna dzieciom szkoła funkcjonuje w jednym z krajów skandynawskich. W innym kraju leżącym na terenie Skandynawii (Dania) zrealizowano program mający pomóc dzieciom z ADHD ${ }^{41}$. Czy ma to związek z brakiem kultury upokarzania? ${ }^{42}$ Jak w takiej szkole funkcjonowałby Krzyś, Jay i podobne do nich dzieci? Jak potoczyłyby się ich losy?

\footnotetext{
$38 \mathrm{~W}$ polskiej szkole „[n]auczyciele (...) mają mało swobody, mało zaufania ze strony dyrektora i instytucji, dla której pracują. Są [też] przytłoczeni ogromem biurokracji. Bo kiedy nie wiadomo jak ocenić szkołę, to ocenia się ją po rankingach i papierach, w których nauczyciele muszą udowadniać, ile codziennie nauczyli. Jak inni mają szanować człowieka, któremu nie ufa jego własny przełożony?" (Klasa ziewających... 2016: 34; por. Zniewolony umysł... 2016: 12).

39 „[P]ierwszych sześć lat to edukacja zintegrowana, zadaniowa, kolejne trzy lata - edukacja kierunkowa, i ogólna, ale w tej samej szkole" (Szkoła szczęśliwszych... 2016: 31). Studia pedagogiczne przygotowują nauczycieli do pracy na wszystkich poziomach edukacji (tamże).

${ }^{40} \mathrm{~W}$ naszych szkołach nie można nawet rozwiązać problemu zbyt ciężkich tornistrów (pap 2016: 2). 0 problemie tym słyszę od lat. Często też widzę małe dzieci, uginające się pod ciężarem wyładowanych po brzegi tornistrów/plecaków. Rodzice są bezradni. Podniosłam kiedyś tornister znajomej uczennicy III klasy, zarzuciłam go na plecy i odprowadziłam dziewczynkę do szkoły. Podniesienie tornistra, w którym nie było ani jednej zbędnej rzeczy, kosztowało mnie sporo wysiłku. Długo też czułam jego ciężar na ramionach. Dzieci dźwigają takie ciężary codziennie. Za kilka lat ustawią się zapewne w kolejce do ortopedy...

${ }^{41}$ Siostrzenica mojej koleżanki, po ukończeniu studiów, otrzymała od przyjaciół rodziców propozycję pracy w Finlandii jako opiekunka do dzieci. Nie zdecydowała się jednak. Czy dziś żałuje ten decyzji? ${ }^{42} \mathrm{Na}$ brak kultury upokarzania w państwach skandynawskich zwrócił uwagę Andrzej Szahaj podczas rozmowy z Michałem Wróblewskim (Szahaj: daliśmy szansę... 2010: 5).
} 


\section{Bibliografia}

ANS (2016) Praca dla osób z autyzmem..., „Angora”, 21.08.2016, nr 34, s. 73.

Andreoli V. (2009) Zrozumieć cierpienie. Aby ból ustąpił radości, tłum. M. Bielawski, Kraków, Wydawnictwo Homini.

Aron E. (1996) The Highly Sensitive Person, New York, Carol Publishing.

Bożeński W. (2000) Pęknięty witraż. Człowiek w pułapce globalizmu, Gdańsk, Andromeda.

Bujak K. (2001) Człowiek zredukowany. Niektóre aspekty wychowania w szkole socjalistycznej, „Zeszyty Naukowe Uniwersytetu Jagiellońskiego. Prace Etnograficzne”, z. 36, s. $131-140$.

Cyrulnik B. (2011) Rozmowy o miłości na skraju przepaści, tłum. E. Kaniowska, Warszawa, Wydawnictwo Czarna Owca.

Dąbrowski K. b.d., Posłanie do nadwrażliwych. http://wiersze.doktorzy.pl/nadwrazliwi.htpm [dostęp: 01.07.2015].

Dąbrowski K. (1958) Nerwowość dzieci i młodzieży, Warszawa, Państwowy Zakład Wydawnictw Szkolnych.

Dąbrowski K. (1975a) Trud istnienia, Warszawa, Wiedza i Życie.

Dąbrowski K. (1975b) Osobowość i jej kształtowanie poprzez dezintegrację pozytywnq, Warszawa, Polskie Towarzystwo Higieny Psychicznej.

Dąbrowski K. (1979) Dezintegracja pozytywna, Warszawa, Państwowy Instytut Wydawniczy.

Firlej K. (2011) Chcemy szkoły pozwalającej rozwinać skrzydła w: Rozwój i edukacja. Wielkie przewartościowanie, J. Szomburg (red.), Gdańsk, Instytut Badań nad Gospodarką Rynkową, s. 97-104.

Foucault M. (2000) Archeologia wiedzy, tłum. A. Siemek, Warszawa, Państwowy Instytut Wydawniczy.

Gaulejac V. de (1996) Les Sources de la honte, Paris, Desclée de Brouwer.

Gleba E. (2010) Dezintegracja psychiczna - wybrane ujęcia, „Current Problems of Psychiatry", vol. 11(4), s. 389-393. 
Jagiełło E. (2012) Antropolog w organizacji. Zapiski z badań terenowych, „Etnografia Polska", t. LVI, z. 1-2, s. 157-176.

Kabzińska I. (2012) Nadwrażliwi - marginalizowana mniejszość kulturowa w: Ciekawość świata, ludzi, kultury... Księga ofiarowana Profesorowi Ryszardowi Kantorowi z okazji czterdziestolecia pracy naukowej, R. Hołda, T. Paleczny (red.), Kraków, Księgarnia Akademia, s. 121-139.

Kabzińska I. (2013) Czy upokarzanie jest „wszechobecne”?, „Etnografia Polska”, t. LVII, z. 1-2, s. 191-214.

Klasa ziewających... (2016) Klasa ziewających Einsteinów. Z Mariq Mach rozmawia Aleksandra Szyłło, „Gazeta Wyborcza”, 10-11.09.2016, s. 34-35.

Kossobudzka M. (2015) ADHD. Wychowywać czy leczyć?, „Gazeta Wyborcza”, 23.09.2015, s. 4-5.

KZ (2016), Te trudne emocje, „Tele Tydzien”, 27.05.-2.06.2016.

Limont W. (2014) „Inny świat? Czy nieznany ich własny?” Potencjał rozwojowy, wzmożona pobudliwość psychiczna a zdolności, „Psychologia Wychowawcza”, nr 5, s. 9-27.

Ojciec Święty Franciszek (2014) Adhortacja Apostolska Evangelii Gaudium. O głoszeniu ewangelii we współczesnym świecie, tłum. K. Stopa, Częstochowa, Edycja Świętego Pawła.

Pap (2016) Szkoła waży, „metrocafe.pl”, 13.09.2016, s. 2.

Perzanowski A. (2009) Odmieńcy. Antropologiczne studium dewiacji, Warszawa, Wydawnictwo DiG.

Potulicka E., Rutkowiak J. (2010) Neoliberalne uwikłania edukacji, Kraków, Oficyna Wydawnicza „Impuls”.

Poza stadem... (2015) Poza stadem. Z Joanna Węgrzynowskq ze stowarzyszenia Bliżej Dziecka rozmawia Aleksandra Szyłło, „Wysokie Obcasy” (dodatek do „Gazety Wyborczej"), 18.07.2015, s. 20-23.

Raport metodologiczny... (2015) Raport metodologiczny - badania „Bezpieczeństwo w szkole, klimat szkoły, klimat klasy", brak red., Warszawa, Instytut Badań Edukacyjnych.

Rydlewski M. (2013) Wszechobecne upokarzanie (na marginesie artykułu Andrzeja Szahaja pod tytułem „Kultura upokarzania”), „Etnografia Polska”, t. LVII, z. 1-2, s. 171-190. 
Solarek L. (2016) Dziewczyna bez ręki, „Angora”, 11.09.2016, nr 37, s. 78-79.

Srebnicki T. (2015) Bardzo grzeczne dzieci, które chcq, ale nie moga, "Gazeta Wyborcza", 23.09.2015, s. 6-7.

Szahaj: daliśmy szansę... (2010) Szahaj: daliśmy szansę Friedmanowi, dajmy teraz Myrdalowi. Wywiad z prof. Andrzejem Szahajem (rozmawiał Michał Wróblewski), wywiad został przeprowadzony 30. 06. 2010, http://www.krytykapolityczna.pl/Wywiady/ Szahaj/Daliśmy_szanse_Friedmanowi_dajmy... [dostęp: 08.01.2013].

Szahaj A. (2012) Kultura upokarzania, „Odra”, nr 2, s. 40-43.

Szkoła szczęśliwszych... (2016) Szkoła szczęśliwszych ludzi. Z Robertem Kwaśnica rozmawia Robert Siewiorek, „Gazeta Wyborcza”, 7-8.10.2016, s. 30-31.

Wadowski J. (2011) Problem godności człowieka w cywilizacji naukowo-technicznej, Konferencja „Nauka - Etyka - Wiara”, Dobieszków koło Łodzi, 23-26.06. 2011, s. 257270; pdf.chfpn.pl/files/?id/plik=471 [dostęp: 12.11.2015].

Zeff T. (2008) Być nadwrażliwym i przetrwać, tłum. E. Abłamowicz, Warszawa, Jacek Santorski \& Co Agencja Wydawnicza, Sp. z o.o.

Zniewolony umysł... (2016) Zniewolony umysł. Z prof. Bogusławem Śliwerskim rozmawiaja Maria Hawranek i Szymon Opryszek, „Gazeta Wyborcza”, 15-16.10.2016, s. 1112.

Żakowski J. (2013a) Nasza złość plemienna, „Polityka”, nr 7, 13.-19.02.2013, s. 15-17.

Żakowski J. (2013b) Odkuwanie głów. Szkoła jest wciąż potrzebna, ale nie taka, „Polityka", nr 20, 15-21.05.2013, s. 16-18. 